\title{
COVID-19 and the Fourth Burden of Women in Developing Countries: A Mini Review
}

\author{
Putri C.Eyanoer $^{1 *}$, Fotarisman Zaluchu ${ }^{2}$ \\ ${ }^{1}$ Department of Community and Preventive Medicine, Faculty of Medicine, Universitas Sumatera Utara, Medan, North \\ Sumatera, Indonesia; ${ }^{2}$ Department of Epidemiology, Faculty of Public Health, Universitas Sumatera Utara, Medan, North \\ Sumatera, Indonesia
}

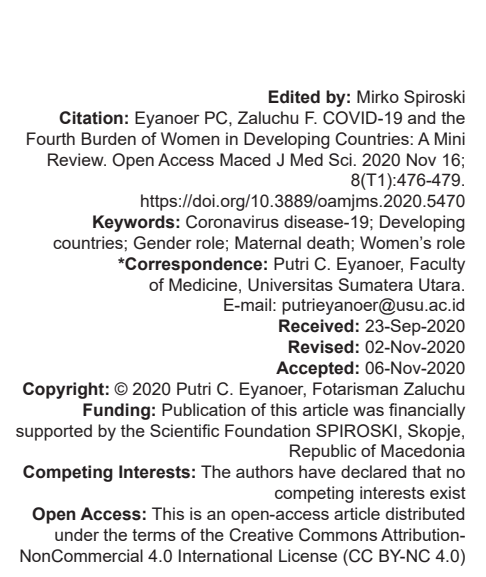

Abstract

It is known that women experience heavier physical and psychological burdens more than men. This is closely related to the traditional role of women because of the absence of women's authority in themselves. In the coronavirus disease (COVID)-19 pandemic situation, the role of women has increased, namely taking on a protective role. With this additional burden, the physical and psychological burden on women becomes heavier and has the potential to create health problems in the future. In this mini review, the authors discuss the potential impact of implementing the COVID-19's prevention protocol on women's lives. It was concluded that there were serious and very large potential consequences for women, in terms of physically, psychologically, or emotionally; thus, early anticipations are really needed.

\section{Introduction}

It has been almost a year that coronavirus disease (COVID)-19 has caused suffering to all people in the world. Based on WHO data, until the middle of September 2020, COVID-19 has created suffering for about 30 million people in the world. Based on a report from Africa and South-East Asia region only, the number of people affected has reached 6.5 million [1]. Unfortunately, until now, there is no vaccine available even though vaccine trials are being carried out by various parties [2].

The immediate impact of COVID-19 is clear. At present, the number of deaths has reached 921,801 deaths [1]. Initially, there was concern about death in the elderly because their immunity is more vulnerable. However, recent data show morbidity rates in a much younger age group. For example, Indonesia notes that half of the positive cases are in the 19-45 year age group [3]. Meanwhile, in England, the 20-39 year age group has up to 10 times the risk of those over 70 years of contracting COVID-19 [4]. These facts show that the current mortality rate is no longer very different for all age groups.
The economic impact of COVID-19 is also visible [5]. The World Bank explained that there has never been a recession so severe, so fast, and so deep since 1990. In addition, this recession is predicted to bring tens of millions of people into extreme poverty [6]. The achievements of the global community during the last 15 years could be instantly collapse so that the global targets that have been formulated in the Sustainable Development Goals are likely to fail [7]. United Nations Development Programme has warned that COVID-19 is not only a health problem but has very serious consequences for the economy and social life [8].

However, one of the impacts that still escapes in-depth discussion is the burden on women. This article is a mini review that will discuss the impact of COVID-19 on women's lives, especially in developing countries, because, until now, there are still too few things about it. This is understandable because the impact of COVID-19 on women may only be felt for some time to come considering that the world community is now focusing on the direct impact of COVID-19. However, if this burden is not anticipated at an early stage, it is not impossible that serious consequences will occur in the lives of women. 


\section{Traditional Role}

In many developing countries, women are often regarded as responsible parties in the traditional role, which are: Productive, reproductive, and social sectors [9]. This occurs because the practices of patrilineal norms do not provide space for women to have sufficient autonomy over themselves [10], [11]. This patrilineal norm maintains the ideal things that must be done by women throughout their life. This norm has been practiced for a long time so that it is not easy to release women from the responsibilities that have become their traditional roles. The norms that place a huge burden on women are no longer questioned so that they are considered the truth [12], [13].

These burdens then cause various health problems for women which can be seen from various indicators. The best example is maternal death. According to the $\mathrm{WHO}$, in 2017, nearly 300 thousand women died during pregnancy and childbirth. That means that every day there are 810 cases of maternal deaths, and 90 percent of them occur in developing countries [14]. This means that in $1 \mathrm{~h}$, about 33 pregnant women died. At this time, maternal mortality ratio in Indonesia is equal to $359 / 100,000$ live births [15].

Maternal death represents a major impact of the women's traditional role. Apart from the direct cause, maternal death cannot be separated from the fact that women do not have autonomy over themselves. A pregnant woman is considered to have no right to herself so that even her own reproductive health decisions, including examining her own pregnancy, let alone recognize danger signs in pregnancy, and even deciding where to give birth, are not in her hands. The low health status of women [15], [16] producing delay after delay in every stage of the pregnancy process, due to decision making by parties outside the pregnant mother, causes pregnant women to experience fatal conditions [17], [18].

Gender inequality is also associated with another issue that has a major impact on women, namely mental health. One of the manifestations of mental disorders is depression, in which women are twice as likely as men [19], [20]. It has been proven that with gender roles that are not too different, the prevalence of mental health disorders in women is reduced [21]. This means that in developing countries where the traditional role of women is still very strong, women are more at risk of experiencing mental disorders because, in these countries, these women experience "structural gender inequity, measured at the macro or societal level" [22]. As explained by $\mathrm{WHO}$, gender affects all structures of society, including in terms of differences in the occurrence of mental health impacts [20].

The two things above have adequately represented the manifestation of the impact of the traditional role of women which is still ongoing in developing countries. In other words, the persistence of the traditional role of women is one of the causes behind women's health problems. Unfortunately, this heavy burden is often maintained by state policies [23], including during the COVID-19's pandemic.

\section{New Normal Policy}

The new normal policy implies the enactment of various important provisions designed by the state to be obeyed by everyone. The provisions have a lot to do with activities from within the family. Among them are washing hands frequently, cleaning the house, consuming healthy food and drinks, including maintaining body immunity.

The Centres for Disease Control and Prevention (CDC) has provided very detailed guidance on preventing the transmission of COVID-19 in households. The guide explains that every house must apply two important principles, namely cleaning and disinfecting [24]. Both of these things must be done in all components of the house such as doors, tables, lamps, or kitchen apparatus. In addition, the CDC complements the manual with technical guidelines that contain detailed procedures necessary for household use [25]. The technical guidelines are also provided in full by $\mathrm{WHO}$, according to the conditions suitable for the individual [26].

It is true that these guidelines are of course made to help everyone avoid the spread of COVID-19 because COVID-19 has now formed household clusters. As a new disease, of course, the entire guide seems very complete and detailed. However, as in the traditional context of roles above, given the very dominant role in the household, it is clear that this heavy burden inevitably ends up being carried by women. Guidelines for handling COVID-19 seem to be made to be implemented by none other than women.

In an atmosphere where every country in the world has entered "new normal," it is clear that women's burden is not lighter; instead, it is multiplying. Apart from the three burdens that had been affixed to her, women must now bear the fourth burden, namely the protective role. The protective task is the role of women in protecting family health to avoid the virus that causes COVID-19.

With a protective role, it is women who play a role in ensuring that the implementation of health guidelines for the prevention of COVID-19 is obeyed by family members. These good practices must be carried out obediently by all family members because the COVID-19 transmission currently relies on prevention through the family. This is where the protective role of women is seen. In this role, women must ensure that all family members carry out clean and good living arrangements and are able to protect the family. 
To prevent COVID-19 transmission in the family, for example, according to the recommendation, every family member must no longer use clothes that have been worn from outside the home. The clothes must be removed immediately and then washed. It is the women who then wash the clothes of all family members, in addition to the routine of washing clothes that they usually do. In developing countries, the availability of clean water is not easy. Women usually have to transport clean water from its source, which is generally quite far away. Imagine how much more burden a woman has to do to protect her family's health.

In addition, women are also the ones who guarantee food and drink for their families. In developing countries, it is women who have a role in fulfilling family needs, including food hygiene and health.

To ensure that food and drinks from outside the house must be guaranteed cleanliness, it is often women who go directly to shop and interact with the traditional markets, where the COVID-19 cluster often occurs. Such activities put women at risk of exposure and or being a carrier. Likewise, to increase body immunity, family members must eat nutritious foods and take vitamins. Those who buy and regulate their use are generally women.

Ironically, for family members to stay healthy, women often choose to maintain the house alone, not wanting to be accompanied, thereby increasing the workload that must be completed alone. Hence, many to-do lists that must be made to be done by women.

This protective role activity clearly had a significant impact on the health of women's bodies, particularly housewives. Physically, women are overloaded because in addition to working on traditional roles, now they have to do new things that are very important and very draining, namely preventing their families from being exposed to COVID-19. Psychological impacts are also expected to occur, although they will only be seen in the future. Even though the COVID-19 guidelines state that everyone's immunity must be maintained in an effort to fight severe acute respiratory syndrome coronavirus 2 virus infection, but it seems that this recommendation does not apply to women. It is not surprising that, based on the survey in Asia Pacific continent, women experience a much higher level of stress than men [27]. This survey, although only represented by a few countries in the region, provides preliminary information on this issue in the world, particularly in developing countries.

With this fourth burden, women's position is getting heavier. Increasing the burden will be increasing women's health risks. This condition, unfortunately, is never be anticipated in implementing the new normal policy. Hence, it can be concluded that the new normal policy is a policy that has a negative impact on the women's lives today and in the future.

\section{Conclusion}

The COVID-19 pandemic is not yet over. Meanwhile, while the traditional roles of women still cause serious problems for women, now women have to bear the burden of protective roles. Great efforts are needed to prevent the impact of these major roles on women's physical and psychological health.

\section{References}

1. WHO. WHO Coronavirus Disease (COVID-19) Dashboard Geneva: WHO; 2020. Available from: https://www.covid19.who. int. [Last accessed on 2020 Sep 27].

2. WHO. The Push for a Covid-19 Vaccine. Geneva: WHO; 2020 Available from: https://www.who.int/emergencies/diseases/ novel-coronavirus-2019/covid-19-vaccines. [Last accessed on 2020 Sep 14].

3. Satuan Tugas Penanganan Covid-19. Peta Sebaran; 2020 Available from: https://www.covid19.go.id/peta-sebaran. [Last accessed on 2020 Sep 15].

4. Editorial. Curing COVID-19. Lancet Infect Dis 2020;3099(20):30706

5. McKinsey. Coronavirus' Business Impact: Evolving Perspective. India: McKinsey; 2020. Available from: https://www.mckinsey. $\mathrm{com} /$ business-functions/risk/our-insights/covid-19-implicationsfor-business. [Last accessed on 2020 Sep 14].

6. World Bank Group. Global Economic Prospects. Washington, DC: The World Bank; 2020.

7. Editorial. Will the COVID-19 Pandemic Threaten the SDGs? Lancet Public Health. 2020;5(9):e460. https://doi.org/10.1016/ s2468-2667(20)30189-4

8. UNDP. Covid-19 Sosio-economic Impact; 2020. Available from: https://www.undp.org/content/undp/en/home/coronavirus/ socio-economic-impact-of-covid-19.html. [Last accessed on 2020 Sep 14].

9. Moser CO. Gender Planning and Development: Theory, Practice and Trainning. London: Routledge; 1993.

10. Connell RW, Messerschmidt JW. Hegemonic masculinity. Gend Soc. 2005;19(6):829-59.

11. Wieringa SE. Passionate aesthetics and symbolic subversion: Heteronormativity in India and Indonesia. Asian Stud Rev. 2012;36(4):515-30. https://doi.org/10.1080/10357 823.2012.739997

12. Bourdieu P, Nice R. Masculine Domination. United Kingdom: Polity Press; 2001.

13. Bourdieu P. Language and Symbolic Power. Cambridge: Polity Press; 2012

14. WHO. Maternal Mortality; 2019. Available from: https://www. who.int/news-room/fact-sheets/detail/maternal-mortality. [Last accessed on 2020 Sep 19].

15. Indonesia Statistics Board, National Population and Family Planning Board, Ministry of Health, and ICF International. Indonesia Demographic and Health Survey 2012. Jakarta: BPS, BKKBN, Kemenkes, and ICF International; 2013. https://doi. org/10.25133/jpssv27n3.0016

16. Campbell OM. What are maternal health policies in developing countries and who drives them? A review of the last half-century. In: De Brouwere V, Van Lerberghe W, editors. Safe Motherhood 
Strategies : A Review of the Evidence. United States: ITG Press; 2001. p. 412-42.

17. Filippi V, Ronsmans C, Campbell OM, Graham WJ, Mills A, Borghi $\mathrm{J}$, et al. Maternal health in poor countries: The broader context and a call for action. Lancet. 2006;368(9546):1535-41. https://doi.org/10.1016/s0140-6736(06)69384-7

PMid:17071287

18. Belton S, Myers B, Ngana FR. Maternal deaths in eastern Indonesia: 20 years and still walking: An ethnographic study. BMC Pregnancy Childbirth. 2014;14:39. https://doi. org/10.1186/1471-2393-14-39

PMid:24447873

19. Thaddeus S, Maine D. Too far to walk: Maternal mortality in context. Soc Sci Med. 1994;38(8):1091-110. https://doi. org/10.1016/0277-9536(94)90226-7 PMid:8042057

20. WHO. Women's Mental Health: An Evidence Based Review. Geneva: WHO; 2000.

21. Howard LM, Ehrlich AM, Gamlen F, Oram S. Genderneutral mental health research is sex and gender biased Lancet Psychiatry. 2017;4(1):9-11. https://doi.org/10.1016/ s2215-0366(16)30209-7

PMid:27856394
22. Kuehner $\mathrm{C}$. Why is depression more common among women than among men? Lancet Psychiatry. 2017;4(2):146-58. https:// doi.org/10.1016/s2215-0366(16)30263-2

PMid:27856392

23. Kar SB, Pascual CA, Chickering KL. Empowerment of women for health promotion:Ameta-analysis. SocSciMed. 1999;49(11):143160. https://doi.org/10.1016/s0277-9536(99)00200-2

24. CDC. Cleaning and Disinfection for Households; 2020. Available from: https://www.cdc.gov/coronavirus/2019-ncov/preventgetting-sick/cleaning-disinfection.html. [Last accessed on 2020 Sep 14].

25. CDC. Guidance for Cleaning and Disinfecting; 2020. Available from: https://www.cdc.gov/coronavirus/2019-ncov/community/cleaningdisinfecting-decision-tool.html. [Last accessed on 2020 Sep 14].

26. WHO. Coronavirus Disease (COVID-19) Advice for the Public 2020. Available from: https://www.who.int/emergencies/ diseases/novel-coronavirus-2019/advice-for-public. [Last accessed on 2020 Sep 14].

27. UN Women. Surveys Show that COVID-19 has Gendered Effects in Asia and the Pacific; 2020. Available from: https:// www.data.unwomen.org/resources/surveys-show-covid-19has-gendered-effects-asia-and-pacific. [Last accessed on 2020 Oct 22]. https://doi.org/10.1596/978-1-4648-1565-2 